\title{
Infekciós ráta gyermekkorban epicutan hagyott tứződrót esetén
}

\author{
DR. BALOGH BRIGITTA, DR. JUHÁSZ LÁSZLÓ, DR. VIZI ANDRÁS,
}

DR. BÁN GYULA, DR. KOVÁCS TAMÁS

\section{ÖSSZEFOGLALÁS}

A gyermekkori elmozdulással járó törések bizonyos formáinak kezelésében (epiphyseolysisek és metaphysis törések) a fedett repozíció és percutan dróttűzés a választandó eljárás. A Kirschner drót vége rövidre vágva a bőr alá süllyeszthető, vagy hosszúra hagyva a bőr felett hagyható. A tűződrót végének epicutan hagyását az infekció veszélye, az elmozdulás lehetősége és a gipsz nehezebb modellálása miatt sokan nem támogatják. Előnye azonban, hogy az epicutan tǔződrót eltávolítása általános vagy helyi érzéstelenítés nélkül, ambulánsan fájdalommentesen elvégezhető. A Szegedi Gyermekklinika Sebészeti Osztályán a fedett és véres repozíciót követő Kirschner drótos fixálás esetén a tűződrót végét a bőr szintje felett hagyjuk. Vizsgálatunk célja az volt, hogy 2007-2012 között végzett percutan Kirschner drótos fixálások esetén a tűződrótok bőrön kívül hagyása fokozta-e az infekciók számát, illetve okozott-e egyéb szövődményt. Az 5 éves intervallumban 161 mútétet végeztünk a fent említett technikával, amelyből mindössze 4 esetben találkoztunk a szúrcsatornából származó, néhány napon belül szűnő serosus váladékozással. Nem fordult elő gennyes váladékozás, suppuratio, mély lágyrész infekció, szeptikus szövődmény, illetve osteomyelitis. A vizsgált időszakban nem tapasztaltunk olyan mértékủ drótelmozdulást, amely a törés redislocatióját okozta volna. Gyermekek esetén az elbuktatott fém eltávolítása sok esetben csak altatásban lehetséges, azonban az epicutan hagyott tǔződrót esetében a rögzítő fémek ambulánsan, érzéstelenítés nélkül, fájdalommentesen eltávolíthatóak. A bőr felett hagyott tǔződrót nem növeli az infekció kialakulásának és a törés redislocatiójának veszélyét.

\section{Kulcsszavak: $\quad$ Gyermekkor; Infekció; Posztoperativ komplikációk; Töréskezelés; Tüzödrót;}

\section{B. Balogh, L. Juhász, A. Vizi, Gy. Bán, T. Kovács: Infection rate of epicutaneous K-wire in childhood}

$\mathrm{K}$-Wire fixation is the treatment of choice in certain displaced fractures (e.g.: epiphyseolysis and metaphyseal fracture) in childhood. The end of the K-wire can either be cut short and recessed beneath the skin level, or cut long and left protruding through the skin. Some surgeons do not prefer epicutaneous K-wire because of the risk of infection, re-displacement and improper application of the cast. However, removal of the epicutaneous wire can be performed in out-patient clinics painlessly without applying general or local anaesthesia. In the Surgical Division of Department of Paediatrics, University of Szeged, the end of the Kwire is left protruding through the skin following either open or closed reduction. The aim of this study was to reveal the number of possible infections and other complications between 2007 and 2012 as a result of K-wires left epicutaneously after percutaneous wire fixation. In the 5-year interval 161 operations were performed with the above-mentioned technique. There were only 4 cases with serous discharge from the pin site, which ceased spontaneously in few days. There were no cases of purulent discharge, suppuration, deep soft tissue infection, septic complication or osteomyelitis. In the interval observed there was no pin migration which caused re-displacement of the fracture. In children the removal of pins cut-off just beneath the skin is possible mainly in general anaesthesia, however, epicutaneous wires can be removed painlessly without applying anaesthesia as an out-patient procedure. Pins protruding through the skin do not increase the risk of infection and fracture re-displacement.

\section{Key words: \\ Adolescent; Bone wires - Adverse effects; Child; Fracture fixation - Methods; Postoperative Complications; Surgical wound infection - Epidemiology;}




\section{BEVEZETÉS}

A gyermektraumatológiai ellátásban is egyre nagyobb szerepet kapnak a minimál invazív beavatkozások (4). Előnyük, hogy kevésbé traumatizálnak, minimális a mútéti vérvesztés, kisebb a mútéti heg és a physist nem károsítják. A percutan dróttǔzés adaptációs stabilitást ad, ezért bizonyos epiphyseolysiseknél, illetve metaphysis töréseknél jól alkalmazható gipszsín felhelyezésével kiegészítve. Leggyakoribb alkalmazási területek a radius distalis vég törései, a humerus supracondyler és proximalis vég törései, a femur distalis epiphysis sérülései és a rövid csöves csontok törései. Martin Kirschner 1909ben vezette be a tǔződrót alkalmazását, azóta kiterjedten alkalmazzák a traumatológiában, ortopédiában $(6,7)$. A törés fedett repozíciója után a tűződrótot percutan bevezetjük a törtvégbe, majd a távoli corticalisban rögzítjük. A drót végét a legtöbb intézetben rövidre vágják, majd a bőr alá süllyesztik az infekció elkerülése és a gipsz pontos felhelyezése érdekében. Klinikánkon ezzel szemben a tűződrót végét a bőr felett mintegy $2 \mathrm{~cm}$-rel vágjuk le, majd az epicutan maradt véget derékszögben meghajlítjuk, megakadályozva a drót elmozdulását. A tűződrót végének epicutan hagyását a gyulladásos szövődmények veszélye, a gipsz nehezebb modellálása és a redislocatio lehetősége miatt sokan nem támogatják (1). Cikkünk célja a drót bőr felett hagyásából adódó szövődmények bemutatása. Előnye, hogy az epicutan tûződrót eltávolítása egy határozott mozdulattal, ambulánsan helyi vagy általános anesztézia nélkül fájdalommentesen végezhető. Gyermekek esetén a bőr alá buktatott fém helyi érzéstelenítésben megkísérelt eltávolítása sok nehézségbe ütközhet, kisebb gyermekeknél pedig csak narcosisban kivitelezhető. A bőr alá buktatott túződrót a legtöbb esetben helyi érzéstelenítésben a korábbi behatolásból eltávolítható, azonban néhány esetben a tűződrót a bevezetés helyétől távol található. Többször közöltek már mellkasba, nyaki lágyrészbe, mediastinumba, szívfalba vándorolt drót eltávolításának nehézségeiről. Néhány meglepő útvonal az irocialomboil, amsilyeket felnôtt pál.. cienseknél észleltek: bal kéz középső ujj MP ízületi dézise után 31 hónappal később szívritmuszavart okozó; clavicula osteosynthesist követően a hasi aortába, lépbe vándorló; distalis radiustörés tǔzését követően vénán keresztül szívbe vándorolt tűződrótról számoltak be, de előfordult kulcscsontból az orbitába történő migráció is $(3,8)$. Az USA-ban csak a magasabb biztosítási csoportba tartozó betegek esetén alkalmazzák a tűződrótok elbuktatását, mivel a fémkivételhez szükséges invazív beavatkozás jobban terheli a költségvetést. Klinikánkon a gyermekek érdekeit nézve a fémkivételt egy rövid ambuláns megjelenés során, helyi vagy általános érzéstelenítés nélkül végezzük.

\section{MÓDSZER, MÜTÉTI TECHNIKA}

A szakma szabályai szerinti előkészítés után fedett vagy nyitott repozíciót végzünk, majd képerősítő alatt, szemellenőrzés mellett 1 vagy több tǔződróttal a törést rögzítjük. A tǔzést követően a drótot 1,5-2 cm-rel a bőr szintje felett vágjuk le (1. ábra). Ezt követően a drótot fél $\mathrm{cm}$-rel a bőr felett derékszögben meghajlítjuk (2. ábra), majd a drót alá dezinficienssel átitatott lapot helyezünk (3. ábra). A pólya felhelyezését követően a drót a gipsz modellálásában nem okoz problémát (4. ábra). 


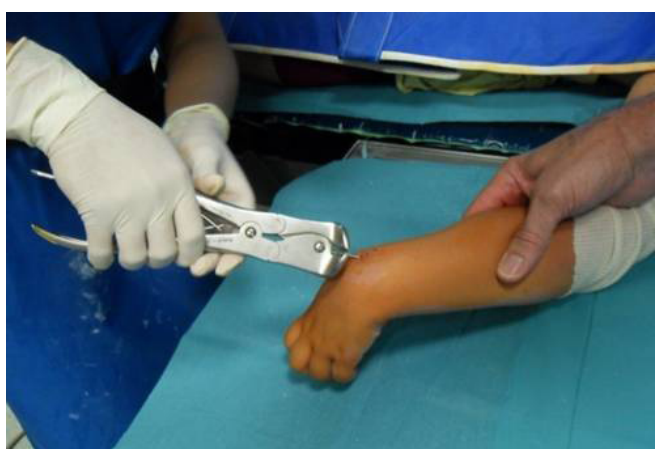

1. ábra A drót végét $1,5 \mathrm{~cm}$-rel a bör szintje felett levágjuk

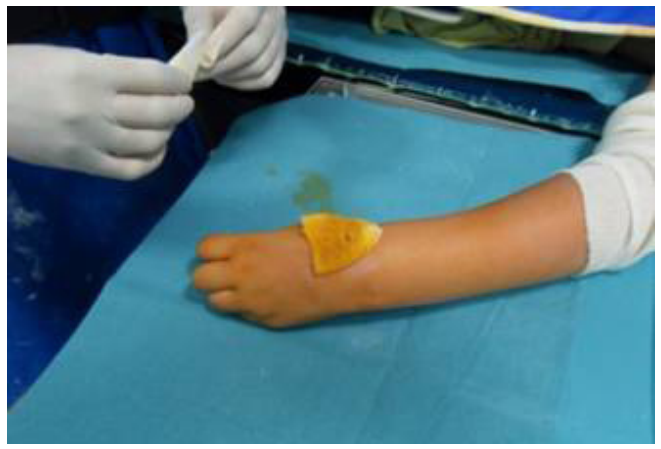

3. ábra Dezinficienssel átitatott lapot helyezünk a drót alá

\section{EREDMÉNY}

2007. január és 2011. december között 161 percutan tüzés történt gyermeksebészeti osztályunkon, amelyből 157 a felső végtagon, 4 az alsó végtagon ( $I$. táblázat). A percutan túzés során a betegek átlagéletkora 8,6 év volt. A legfiatalabb 2 éves kislány, míg a legidősebb 16 éves fiú volt. A fiú : lány arány $1,5: 1$. A sérülés leggyakrabban esés, magasból esés vagy sportolás közben történt. A bal oldali végtag $2 x$ gyakrabban sérült, mint a jobb oldali.

A törés lokalizációjától és stabilitásától függően egy vagy két drótot helyezünk be. Könyöktáji törés esetén minimum két $\mathrm{K}$-dróttal rögzítjük a törést, csukló vagy rövid csöves csontok esetén egy drót is elegendő lehet.

$\mathrm{Az}$ 5. ábrán látható protokollt felső végtagi törések esetén alkalmazzuk, természetesen minden törést individuálisan kezelünk. A harmadik heti kontrollröntgen alapján döntünk az esetleges fémeltávolításról. Nem megfelelő

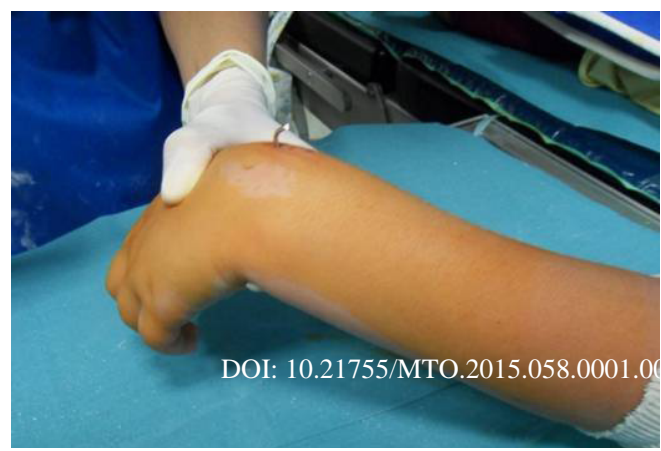

2. ábra A drót végét derékszögben meghajlítjuk

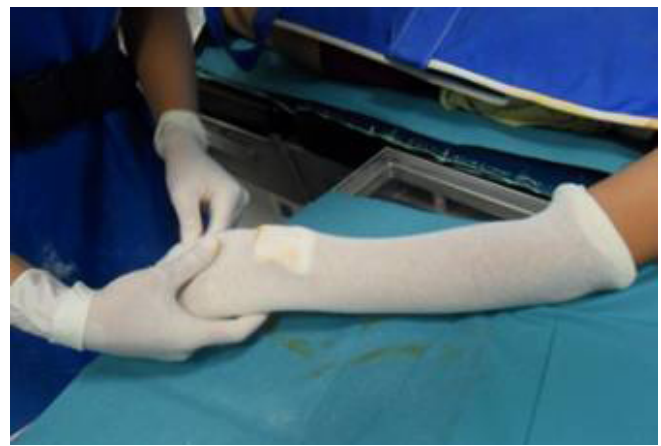

4. ábra A pólya felhelyezését követöen kiemelten fontos a gipsz megfelelő modellálása

callusképződés esetén egy hét múlva ismételjük a röntgenvizsgálatot. A tűződrótokat leghamarabb a 21. napon távolítottuk el. Az epiphyseolysis capitis femoris esetén a tűződrótokat elbuktattuk és fél év után altatásban távolítottuk el.

A bőrön kívül hagyott tüződrót öt esetben csúszott a bőr alá, négy esetben lokális anesztéziát alkalmazva kis feltárásból távolítottuk el a túződrótokat. Egy esetben a gyermek korára való tekintettel altatásban történt a fémkivétel. Drótelmozdulást nyolc esetben tapasztaltunk, azonban egy esetben sem vált a törés instabillá és redislocatio sem történt, így reoperációra sem volt szükség.

A heti rendszerességű dezinficiálás mellett négy betegnél tapasztaltunk kis mennyiségú serosus váladékozást, amely a drótápolás után spontán, antibiotikum adása nélkül a következő kontrollvizsgálatra megszűnt. Gennyes váladékozás, mély lágyrészinfekció, osteomyelitis egy 
esetben sem alakult ki (II. táblázat).

$A z$ alsó végtagi törések között csak 1-1 olyan esetet észleltünk, ahol percutan túzés vált indikálttá. A betegek 10 év felettiek voltak, főként a bal oldali végtag sérült. Dróteltávolítást áltagban 4 hét után végeztünk, azonban a gipszrögzítést tovább folytattuk.
Szövődményünk nem jelentkezett.

$\mathrm{Az}$ alsó végtagi dróttúzések közül az epiphyseolysis capitis femorist emelném ki (2, 5, 9). Ez az egyetlen betegség, amely során a percutan tűződrótot rövidre vágjuk, majd bőr alá bújtatjuk. Ez esetben az eltávolítás is narcosisban zajlik, mintegy fél év után.

\section{A drótápolás a következö protokoll szerint müködik klinikánkon felső végtagi törés esetén: \\ 0. nap: lemosás, tǔzés, drótápolás, gipszsín \\ 1. nap: Ko. Rtg., drótpótlás gipszátpólyázás \\ 7. nap: Ko. Rtg., drótpótlás gipszátpólyázás \\ 14. nap: drótápolás, gipszsín \\ 21. nap: Ko. Rtg., drótkivétel (gipszrövidítés) \\ 28. nap: szökség esetén Ko. Rtg., gipszlevétel}

5. ábra Kontrollvizsgálatok és drótápolás protokollja osztályunkon

\begin{tabular}{|c|c|c|c|c|c|c|c|c|c|c|}
\hline Fractura & $\begin{array}{l}\text { supracond. } \\
\text { humeri } \\
51 \text { eset }\end{array}$ & $\begin{array}{l}\text { cond. és } \\
\text { epicond. lat. } \\
\text { humeri } \\
15 \text { eset }\end{array}$ & $\begin{array}{c}\text { cond. med. } \\
\text { humeri } \\
7 \text { eset }\end{array}$ & $\begin{array}{c}\text { antebrachii } \\
47 \text { eset }\end{array}$ & $\begin{array}{c}\text { radii } \\
33 \text { eset }\end{array}$ & $\begin{array}{l}\text { digiti } \\
\text { manus } \\
4 \text { eset }\end{array}$ & $\begin{array}{l}\text { femoris } \\
1 \text { eset }\end{array}$ & $\begin{array}{l}\text { tibiae } \\
1 \text { eset }\end{array}$ & $\begin{array}{l}\text { digiti } \\
\text { pedis } \\
1 \text { eset }\end{array}$ & $\begin{array}{c}\text { epiphy- } \\
\text { seolysis } \\
\text { capitis } \\
\text { femoris } \\
1 \text { eset }\end{array}$ \\
\hline életkor (év) & 6,9 & 8,2 & 10 & 9,5 & 9,2 & 10 & 14 & 12 & 10 & 11 \\
\hline $\begin{array}{c}\text { nem } \\
\text { (lány : fiú) }\end{array}$ & $28: 23$ & $5: 10$ & $3: 4$ & 11:36 & 15:18 & $3: 1$ & $0: 1$ & $0: 1$ & $1: 0$ & $1: 0$ \\
\hline $\begin{array}{l}\text { mechaniz- } \\
\text { mus }\end{array}$ & $\begin{array}{l}\text { esés, } \\
\text { magas- } \\
\text { ból esés, } \\
\text { sport }\end{array}$ & $\begin{array}{l}\text { esés, ma- } \\
\text { gasból esés, } \\
\text { sport }\end{array}$ & $\begin{array}{l}\text { esés, } \\
\text { kerékpár }\end{array}$ & $\begin{array}{l}\text { sport, } \\
\text { magasról } \\
\text { esés }\end{array}$ & $\begin{array}{c}\text { magas- } \\
\text { ból esés, } \\
\text { sport, } \\
\text { gázolás }\end{array}$ & $\begin{array}{c}\text { korcsolya, } \\
\text { kés }\end{array}$ & $\begin{array}{l}\text { padba } \\
\text { akadt }\end{array}$ & $\begin{array}{l}\text { ma- } \\
\text { gasból } \\
\text { esés }\end{array}$ & lépcső & $\begin{array}{l}\text { Epiphy- } \\
\text { seolysis }\end{array}$ \\
\hline $\begin{array}{l}\text { oldaliság } \\
\text { (I.s: I.d) }\end{array}$ & $36: 15$ & 11:4 & $4: 3$ & 28:19 & $24: 9$ & $2: 2$ & $1: 0$ & 1:0 & $1: 0$ & $0: 1$ \\
\hline $\begin{array}{l}\text { drót szám } \\
\text { (K: Kirschner } \\
\text { drót) }\end{array}$ & $\begin{array}{c}2 \mathrm{~K}: 48 \\
3 \mathrm{~K}: 3\end{array}$ & $2 \mathrm{~K}: 15$ & $2 \mathrm{~K}: 7$ & $\begin{array}{c}1 \mathrm{~K}: 39 \\
2 \mathrm{~K}: 8\end{array}$ & $\begin{array}{c}1 \mathrm{~K}: 26 \\
2 \mathrm{~K}: 7\end{array}$ & $\begin{array}{l}1 \mathrm{~K}: 2 \\
2 \mathrm{~K}: 2\end{array}$ & $2 \mathrm{~K}$ & $1 \mathrm{~K}$ & $1 \mathrm{~K}$ & $3 \mathrm{~K}$ \\
\hline $\begin{array}{l}\text { drót kivétel } \\
\text { (nap) }\end{array}$ & 23 & 23 & 24 & 25 & 29 & 21 & 28 & 28 & 27 & fél év \\
\hline $\begin{array}{c}\text { drót } \\
\text { elmozdulás }\end{array}$ & 3 & - & - & 4 & 1 & - & - & - & - & - \\
\hline Váladékozás & 1 serosus & - & 1 serosus & 1 serosus & 1 serosus & - & - & - & - & - \\
\hline $\begin{array}{l}\text { bőr alá } \\
\text { csúszás }\end{array}$ & 1 (narcosis) & - & - & - & 4 & - & - & - & - & - \\
\hline
\end{tabular}




\section{II. táblázat Percutan dróttüzés utáni szövődményráta}

\begin{tabular}{|c|c|c|}
\hline & Esetszám & Százalékos megoszlás \\
\hline Drót elmozdulás & 8 & $4,9 \%$ \\
\hline Serosus váladékozás & 4 & $2,5 \%$ \\
\hline Bőr alá csúszás & 5 & $3,6 \%$ \\
\hline Bőr ulceratio & 2 & $1,25 \%$ \\
\hline Suppuratio & 0 & $0 \%$ \\
\hline Osteomyelitis & 0 & $0 \%$ \\
\hline
\end{tabular}

\section{KÖVETKEZTETÉS}

Összegzésként kiemelném, hogy a 161 esetből kevesebb, mint 5\%-ban tapasztaltunk minimális drótelmozdulást, egy esetben sem okozott olyan mértékú redislocatiót, amely miatt reoperációra került volna sor. A fenti eredmény alapján kimondhatjuk, hogy a gipsz modellálásában és a törés megtámasztásában nem okozott jelentős problémát a tűződrót bőr felett maradt vége. Öt esetben a drót a bőr alá csúszott, ezért egy esetben narkózisban, négy esetben helyi érzéstelenítésben távolítottuk el a fémeket. A tűződrót szúrcsatornájából négy esetben tapasztaltunk minimális serosus váladékozást, amely a következő kontrollvizsgálatra spontán megszűnt. Egy esetben sem volt szükség korábbi dróteltávolításra, vagy antibiotikum alkalmazásra. Súlyos lágyrészinfekció, suppuratio, osteomyelitis nem csak az 5 éves időszak alatt, de a több évtizedes gyakorlatban sem fordult elő. A percutan tűződrót bőr felett hagyása nem fokozza az infekciós szövődmények kialakulását. Kiemelkedően fontos a rendszeres és alapos sebtoilette, amelyhez szükség van a heti rendszerességű kontrollvizsgálatokra. A drót eltávolítása altatás, vagy helyi érzéstelenítés nélkül, fájdalommentesen kivitelezhető. 


\section{IRODALOM}

1. Ahmad A., Asif M. Q., Zain A.: Pin tract infection rates between percutaneous and buried K-wires in supracondylar fracture of humerus in children Pak. J. Surg. 2010. 26. (2): 146-150.

2. Boero S., Brunenghi G. M., Carbone M., Stella G., Calevo M. G..; Pinning in slipped capital femoral epiphysis: long-term follow-up study. J. Pediatr. Orthop. B. 2003. 12. (6): 372-379.

3. Gloviczki B.: Tüződrótok vándorlása. Magyar Traumatológia Ortopédia Kézsebészet Plasztikai Sebészet, 2008. 51 . (1): 79-83.

4. Hargitai E.: Minimál invazív beavatkozások. In: Ács G., Hargitai E. (szerk.): Gyermektraumatológia. Budapest, 2001. 573583. $p$.

5. Mann D. C.: Endocrine disorders and orthopedic problems in children. Curr. Opin. Pediatr. 1996. 8. (1): 68-70.

6. Mostafa F. M., El-Ald G., Enan A.: Percutaneous Kirschner-wire fixation for displaced distal forearm fractures in children. Acta Orthop. Belg. 2009. 75. 459-466.

7. Sharma H., Taylor G. R., Clarke N. M. A.: Review of $K$-wire related complications in the emergency management of paediatric upper extremity trauma. Ann. R. Coll. Surg. Engl. 2007. 89. (3): 252-258.

8. Végh Gy. P.: A baleseti sebészeti implantátumok eltávolitásának kérdései. Magyar Traumatológia Ortopédia Kézsebészet Plasztikai Sebészet, 2009. 52. (3): 259-267.

9. Weiner D.: Pathogenesis of slipped capital femoral epiphysis: current concepts. J. Pediatr. Orthop. B. 1996. 5. (2): 67-73.

\section{Dr. Balogh Brigitta}

6724 Szeged, Korányi fasor 14-15.

Mobil: +36-20-6612899

dr.balogh.brigitta@hotmail.hu

\section{Kézsebész szerkesztői vélemény:}

Olvasóink tájékoztatására közöljük, hogy a Szerzők rendkívül korrekt, hiteles feldolgozásban, egy hazánkban eddig általánossá nem váló nagy beteganyagon alkalmazott, új mútéti technikát, az „epicutan hagyott tűződrót” módszerét publikálják. Dolgozatukról a Lektorok pozitív értékeléssel nyilatkoztak, a Szerkesztőbizottságban azonban vita alakult ki, hogy az évtizedekig eredményesen, szövődménymentesen alkalmazott, a tűződrót-végeket fedetté tett technika helyett, tanácsos-e alkalmazni Szerzők módszerét.

Saját véleményem: Eddigi gyakorlatunkban sem volt könnyű megszervezni a tűződrótok eltávolítását. Nem vagyok híve sem a kicsiny, sem a nagyobb gyermekeknél az ambulanter elvégezhető rövid narkózisnak, mert sokkal súlyosabb szövődményei lehetnek az altatásnak!!! Napjainkban az egészségügy létszám- és kapacitásszúkítő jövőjében még nehezebb lesz a „fedett drótok" eltávolítása, akár ambulanter, akár hospitalizált gyereknél.

Összegezve: Mindenképpen javaslom a közlemény megjelenését! A módszer feltétele: a töréskezelés teljes ideje alatt a drótvég körüli területen a legteljesebb asepsis biztosítandó!

Prof. Emer. Dr. Renner Antal 